\title{
Studi Deskriptif Pemberian Obat Pasien Hipertensi Di Puskesmas Tanjungsari Kecamatan Natar Kabupaten Lampung Selatan
}

\author{
Yusrizal $\mathrm{Ch}^{1}$, Dias Ardini ${ }^{2}$ \\ ${ }^{1}$ Jurusan Analis Kesehatan Politeknik Kesehatan Tanjungkarang \\ ${ }^{2}$ Jurusan Farmasi Politeknik Kesehatan Tanjungkarang
}

\begin{abstract}
Abstrak
Hipertensi merupakan penyakit yang sering di temukan di Indonesia. Dikatakan menderita hipertensi apabila tekanan darah sistolik $>140 \mathrm{mmHg}$ dan tekanan distolik $>90 \mathrm{mmHg}$. Tujuan pengobatan hipertensi untuk mengendalikan tekanan darah dengan maksud mencegah komplikasi penyakit. Tujuan penelitian adalah bersifat observasional yang deskriptif. Penelitian ini dilakukan dengan mengambil data penderita hipertensi dalam buku register pasien hipertensi di puskesmas Tanjungsari pada bulan Januari-April 2018. Jumlah pasien penderita hipertensi berjumlah 265 orang. Hasil penelitian di Puskesmas Tanjungsari dapat dilihat bahwa penderita hipertensi berdasarkan jenis kelamin didapatkan bahwa perempuan $(71,13 \%)$ lebih banyak menderita hipertensi dibandingkan laki-laki, kategori umur terbanyak pada usia $>40$ tahun, berdasarkan stadium hipertensi, ringan $(69,05 \%)$, hipertensi sedang $(29,05 \%)$ dan hipertensi stadium berat $(1,99 \%)$, kategori distribusi frekuensi jumlah obat adalah 2 obat hipertensi yaitu captopril dan amlodipin, kategori frekuensi tekanan darah dan penggunaan obat bahwa hipertensi ringan, sedang hingga berat diberikan hanya dengan 2 obat hipertensi, dibuktikan dari data yang di dapatkan adalah diberikan nya Captopril (60\%) pada pasien hipertensi ringan sedang hingga (1\%) pada pasien hipertensi berat. Pada obat amlodipin di berikan kepada pasien hipertensi ringan sedang ( $38 \%)$ hingga pasien hipertensi berat sebanyak $(1,5 \%)$.
\end{abstract}

Kata Kunci: Hipertensi, Pemberian Obat

\section{Descriptive Study of Provision of Medication for Hypertensive Patients in Tanjungsari Health Center, Natar District, South Lampung Regency}

\begin{abstract}
Hypertension is a disease that is often found in Indonesia. It is said to suffer from hypertension if systolic blood pressure $>140 \mathrm{mmHg}$ and distolic pressure $>90 \mathrm{mmHg}$. The goal of treating hypertension is to control blood pressure with the intention of preventing complications of the disease. The purpose of the study was descriptive observational. This study was conducted by taking data on hypertensive patients in the register of hypertensive patients in Tanjungsari health center in January-April 2018. The number of patients with hypertension was 265 people. The results of the research at Tanjungsari Community Health Center can be seen that hypertension patients based on sex found that women $(71.13 \%)$ had more hypertension than men, the highest age category at age> 40 years, based on hypertension stage, mild (69.05\%), moderate hypertension $(29.05 \%)$ and severe stage hypertension (1.99\%), the frequency distribution category for the number of drugs was 2 hypertension drugs namely captopril and amlodipine, blood pressure frequency category and drug use that mild, moderate to severe hypertension was given only with 2 hypertension drugs, evidenced from the data obtained was given Captopril $(60 \%)$ in patients with mild to moderate hypertension $(1 \%)$ in patients with severe hypertension. Amlodipine is given to patients with moderate to mild hypertension (38\%) to severe hypertensivepatients (1.5\%).
\end{abstract}

Keywords: Hypertension,Drug Admin

Korespondensi: Yusrizal Ch, Jurusan Analis Kesehatan, Politeknik Kesehatan Tanjungkarang, Jalan. SoekarnoHatta No. 1 Bandar Lampung, mobile phone: 0811722134, e-mail: yusrizal@poltekkes-tjk.ac.id 


\section{Pendahuluan}

Hampir 1 milyar orang diseluruh dunia memiliki tekanan darah tinggi. Hipertensi adalah salah satu penyebab utama kematian dini diseluruh dunia. Diperkirakan di tahun 2020 sekitar 1,56 miliar orang dewasa akan hidup dengan hipertensi. Hipertensi membunuh hampir 8 miliyar orang setiap tahun di dunia dan hampir 1,5 juta orang setiap tahunnya di kawasan Asia Timur-Selatan. Sekitar sepertiga dari orang dewasa di Asia Timur-Selatan menderita hipertensi (WHO, 2015).

Secara global WHO (World Health Organization) memperkirakan penyakit tidak menular menyebabkan sekitar $60 \%$ kematian dan $43 \%$ kesakitan di seluruh dunia. Perubahan pola struktur masyarakat dari agraris ke industri dan perubahan gaya hidup, sosial ekonomi masyarakat diduga sebagai suatu hal yang melatarbelakangi meningkatnya prevalensi penyakit tidak menular, sehingga angka kejadian penyakit tidak menular semakin bervariasi dalam transisi epidemiologi. Salah satu penyakit yang termasuk dalam kelompok penyakit tidak menular tersebut yaitu hipertensi. Hipertensi selain dikenal sebagai penyakit, juga merupakan faktor risiko penyakit jantung, pembuluh darah, ginjal, stroke dan diabetes mellitus (Depkes RI,2013).Menurut American Heart Association (AHA), penduduk Amerika yang berusia diatas 20 tahun menderita hipertensi telah mencapai angka hingga 74,5 juta jiwa, namun hampir sekitar 9095\% kasus tidak diketahui penyebabnya (Kemenkes RI, 2014).

Berdasarkan data dari Riskesdas Litbang Depkes (2013), hipertensi di Indonesia merupakan masalah kesehatan dengan prevalensi yang tinggi yaitu sebesar 25,8\%. Prevalensi tertinggi di Bangka Belitung $(30,9 \%)$, diikuti Kalimantan Selatan $(30,8 \%)$, Kalimantan Timur (29,6\%), Jawa Barat(29,4\%), Gorontalo $(29,4 \%)$ dan provinsi Lampung adalah $(24 \%)$.

Berdasarkan data hipertensi Kabupaten Kota Provinsi Lampung Lampung Selatan menunjukan bahwa pasien hipertensi laki-laki 8.079 dan pasien hipertensi perempuan mencapai 9.725 dengan mendapati Lampung Selatan urutan pertama dalam data dengan hipertensi terbanyak di wilayah Provinsi Lampung. Berdasarkan hasil data pra survey di Puskesmas Tanjung Sari kecamatan Natar Lampung Selatan tahun 2017 di dapatkan prevalensi pasien hipertensi $(27,91 \%)$ dari 2814 pasien yang berobat di puskesmas Tanjung Sari.
Kemudian pada tahun 2018 pada bulan Januari-April adalah $27,8 \%$ pasien yang berobat di puskesmas Tanjung Sari.

Diperlukan berbagai upaya untuk meningkatkan kepatuhan pasien terhadap terapi obat demi mencapai target tekanan darah yang diinginkan. Paling sedikit $50 \%$ pasien yang diresepkan obat antihipertensi tidak meminum obat sesuai yang direkomendasikan. Tujuan dari pengobatan hipertensi adalah untuk mengendalikan tekanan darah dengan maksud mencegah komplikasi penyakit (Depkes, 2007).

Menurut pedoman pengobatan dasar di Puskesmas untuk penyakit hipertensi obat-obat yang digunakan adalah Hidroklorotiazid, Reserpin, Propanolol, Kaptopril, dan Nifedipin, sedangkan yang tersedia di Puskesmas Tanjung sari adalah Hidroklorotiazid, Kaptopril, Nifedipin, dan Amlodipin. Penelitian ini bertujuan untuk mengetahui gambaran pemberian obat hipertensi di Puskesmas Tanjung Sari dengan umur pasien, jumlah kunjungan pasien beserta jenis kelamin, pengukuran tekanan darah, jumlah obat, dan persentase pemberian dosis obat dan efek obat.

\section{Metode}

Penelitian ini adalah penelitian observasional bersifat deskriptif. Dilaksanakan di Puskesmas Tanjungsari pada bulan Mei-Juli 2018. Sampel dalam penelitian ini adalah penderita hipertensi yang terdaftar dalam buku register dan berobat di Puskesmas Tanjungsari pada bulan Januari-April 2018. Instrumen yang digunakan dalam penelitian ini adalah Data Sekunder dari Laporan Bulanan Puskesmas Tanjung Sari Januari-April tahun 2018. Data yang diambil meliputi jenis kelamin pasien, umur pasien, tekanan darah pasien, Pemberian Jumlah obat, Persentase pemberian Obat. Data yang dikumpulkan dianalisis dengan menghitung persentase penggunaan obat, dihitung dengan rumus: $P=F / N x 100$ Dimana $P$ $=$ persentase, $\mathrm{f}=$ frekuensi, $\mathrm{N}=$ Jumlah Pasien Hipertensi, $100=$ nilai konstan

\section{Hasil}

Tabel.1 Distribusi Frekuensi Jumlah Pasien Penderita Hipertensi di Puskesmas Tanjungsari Natar Lampung Selatan

\begin{tabular}{clcc}
\hline No & Jenis Kelamin & Jumlah & Persentase \% \\
\hline 1 & Laki-laki & 76 & 28,67 \\
\hline 2 & Perempuan & 189 & 71,33 \\
\hline & Total & 265 & 100 \\
\hline
\end{tabular}


Tabel 2 Frekuensi Umur Pasien Penderita Hipertensi di Puskesmas Tanjungsari Natar Kabupaten Lampung Selatan

\begin{tabular}{cccccccc}
\hline \multirow{2}{*}{ No } & \multirow{2}{*}{$\begin{array}{c}\text { Rentang Umur } \\
\text { (tahun) }\end{array}$} & \multicolumn{2}{c}{ Laki-laki } & \multicolumn{2}{c}{ Perempuan } & \multicolumn{2}{c}{ Jumlah } \\
\cline { 3 - 8 } & Jumlah & $\%$ & Jumlah & $\%$ & Jumlah & $\%$ \\
\hline 1. & $<40$ & 2 & 0,75 & 23 & 8,68 & 25 & 9,43 \\
\hline 2. & $40-49$ & 8 & 3,02 & 46 & 17,36 & 54 & 20,38 \\
\hline 3. & $50-59$ & 33 & 12,45 & 58 & 21,89 & 91 & 34,34 \\
\hline 4. & $60-69$ & 24 & 9,06 & 40 & 15,09 & 64 & 24,15 \\
\hline 5. & $70-79$ & 6 & 2,26 & 3 & 1,13 & 9 & 3,39 \\
\hline 6. & $>80$ & 3 & 1,13 & 19 & 7,17 & 22 & 8,30 \\
\hline & Total & 76 & 28,67 & 189 & 71,32 & 265 & 100 \\
\hline
\end{tabular}

Tabel 3 Frekuensi Tekanan Darah Pasien Penderita Hipertensi di Puskesmas Tanjungsari Natar Lampung Selatan

\begin{tabular}{|c|c|c|c|}
\hline No & Tekanan Darah & Jumlah & $\begin{array}{c}\text { Persentase } \\
\%\end{array}$ \\
\hline 1 & $\begin{array}{l}\text { Hipertensi } \\
\text { Stadium Ringan: } \\
\text { Sistolik 140-159 } \\
\text { mm Hg } \\
\text { Diastolik 90-99 } \\
\text { mm Hg }\end{array}$ & 183 & 69,05 \\
\hline 2 & $\begin{array}{l}\text { Hipertensi } \\
\text { Stadium Sedang: } \\
\text { Sistolik 160-179 } \\
\text { mm Hg } \\
\text { Diastolik 100-109 } \\
\text { mm Hg }\end{array}$ & 77 & 29,05 \\
\hline 3 & $\begin{array}{l}\text { Hipertensi } \\
\text { Stadium Berat: } \\
\text { Sistolik 180- } 209 \\
\mathrm{~mm} \mathrm{Hg} \\
\text { Diastolik 110-119 } \\
\mathrm{mm} \mathrm{Hg} \\
\end{array}$ & 5 & 1,99 \\
\hline & TOTAL & 265 & 100 \\
\hline
\end{tabular}

Tabel 4. Frekuensi Jumlah Obat Pasien Penderita Hipertensi di Puskesmas Tanjungsari Natar Lampung Selatan

\begin{tabular}{cccc}
\hline No & Jumlah Obat & Jumlah & $\begin{array}{c}\text { Persentase } \\
\%\end{array}$ \\
\hline 1 & 1 -3 obat & 265 & 100 \\
\hline & Total & 265 & 100 \\
\hline
\end{tabular}

Tabel 5 Nama Obat Hipertensi di Puskesmas Tanjungsari Natar Lampung Selatan

\begin{tabular}{cccc}
\hline No & Nama Obat & $\begin{array}{c}\text { Jumlah } \\
\text { Obat }\end{array}$ & Persentase \% \\
\hline 1 & Captopril & 160 & 60.38 \\
\hline 2 & Amlodipin & 105 & 39.62 \\
\hline & Total & 265 & 100 \\
\hline
\end{tabular}

Tabel 6 Frekuensi Pemberian Obat dengan Tekanan Darah Pasien Penderita Hipertensi di Puskesmas Tanjungsari Natar Lampung Selatan

\begin{tabular}{|c|c|c|c|c|c|c|c|c|c|c|}
\hline \multicolumn{11}{|c|}{ Pengukuran Tekanan Darah } \\
\hline \multirow{2}{*}{ No } & \multirow{2}{*}{ Nama Obat } & Normal & \multicolumn{2}{|c|}{ Ringan-Sedang } & \multicolumn{2}{|c|}{ Berat } & \multicolumn{2}{|c|}{$\begin{array}{c}\text { Sangat } \\
\text { Berat }\end{array}$} & \multicolumn{2}{|c|}{ Jumlah } \\
\hline & & $\mathrm{N} \%$ & $\mathrm{~N}$ & $\%$ & $\mathrm{~N}$ & $\%$ & $\mathrm{~N}$ & $\%$ & $\mathrm{~N}$ & $\%$ \\
\hline 1 & Kaptopril 12,5 mg & & 159 & 60 & 1 & 0,38 & & & 160 & 60,38 \\
\hline 2 & Amlodipin & & 101 & 38,11 & 4 & 1,51 & & & 105 & 39,62 \\
\hline
\end{tabular}




\section{Pembahasan}

Berdasarkan penelitian yang telah dilakukan didapatkan bahwa perempuan $(71,13 \%)$ lebih banyak menderita hipertensi dibandingkan laki-laki. Hal ini sesuai dengan pernyataan dari Bustan (2007) bahwa perempuan lebih besar risiko hipertensi dibandingkan laki-laki. Jika dilihat dari kategori umur, hasil penelitian di Puskesmas Tanjungsari menunjukan bahwa lebih banyak pasien yang menderita hipertensi yang berusia $>40$ tahun. Ini sesuai dengan pernyataan bahwa tekanan darah meningkat dimulai sejak umur 40 tahun (Benedicta,2012).

Dilihat dari distribusi frekuensi tekanan darah pasien didapatkan hipertensi stadium ringan $(69,05 \%)$, hipertensi sedang $(29,05 \%)$ dan hipertensi stadium berat $(1,99 \%)$. Jika sudah terdiagnosa tekanan darah lebih dari normal maka pasien harus berhati hati dan sesering mungkin mengontrol tekanan darah supaya tidak berisiko penyakit kardiovaskuler. Pernyataan ini didukung oleh Kabo (2010) yang menyatakan bahwa tekanan darah dapat mengakibatkan meningkatnya penyakit kardiovaskuler. Semakin tinggi tekanan darah, semakin tinggi risiko terjadinya penyakit jantung koroner, gagal jantung, strok, dan gagal ginjal. Oleh sebab itu hipertensi harus diobati dan dikontrol.

Distribusi frekuensi jumlah obat di Puskesmas Tanjungsari didapatkan bahwa jumlah obat hipertensi yang di berikan adalah hanya 1-2 obat yaitu captopril dan amlodipin. Kemudian frekuensi tekanan darah dan penggunaan obat didapatkan bahwa hipertensi ringan, sedang hingga berat diberikan hanya dengan 2 obat hipertensi tersebut dibuktikan dari data yang di dapatkan adalah diberikan nya Captopril $(60 \%)$ pada pasien hipertensi ringan sedang hingga (1\%) captopril diberikan pada pasien hipertensi berat. Pada obat amlodipin di berikan kepada pasien hipertensi ringan sedang ( $38 \%$ ) hingga pasien hipertensi berat sebanyak $(1,5 \%)$. Dari data di atas dapat dilihat bahwa, Kaptopril banyak diberikankan pada semua jenis hipertensi. Hal ini sesuai dengan ACE-Inhibitor, dengan mekanisme kerja dari golongan ini yaitu sebagai penghambat angiotensi II yang menyebabkan penyempitan pembuluh darah dan berakibat tekanan darah akan meningkat. Pembentukan angiotensin II ini memerlukan suatu enzim yang disebut agiotensin converting enzyme, yang merubah angiotensin I menjadi angiotensin II. Jadi dengan menghambat produksi angiotensin II maka dinding pembuluh darah akan melebar, berakibat turunnya tekanan darah. (Tjay dan Rahardja, 2007).
Ada juga obat yang diberikan dari golongan antagonis kalsium untuk semua jenis hipertensi, yaitu Nifedipin dan Amlodipin. Obat ini sangat bermanfaat mengatasi hipertensi darurat karena dosis awalnya yaitu $10 \mathrm{mg}$ dapat menurunkan darah dalam waktu 10 menit (Nafrialdi, 2008). Dari data di atas dapat dilihat bahwa, terdapat pemberian obat dari golongan ini pada jenis ringan sedang hingga hipertensi berat. Menurut Tjay dan Rahardja (2007) obat ini digunakan pada hipertensi ringan- sedang. Jadi pemberian obat pada pasien dengan hipertensi barat sampai berat sekali tidak efektif. Mekanisme kerja dari golongan obat ini yaitu menghambat ion kalsium yang menyebabkan tekanan darah. Ion kalsium ini sangat penting untuk pembentukan tulang dan otot polos jantung, akibat terjadi rangsangan maka ion kalsium yang ada di luar sel akan masuk ke dalam sel, sehingga makin banyak ion kalsium di sel, dan terjadilah kontraksi otot jantung dan arteri menciut dan mengakibatkan tekanan darah meningkat (Tjay dan Rahardja,2007).

Sedangkan menurut Depkes (2007) Standar Pengobatan Puskesmas untuk penyakit hipertensi menggunakan obat Hidroklorotiazid, Kaptopril, Reserpin, Propanolol, dan Nifedipin. Tetapi, berdasarkan observasi dan melihat dari standar pengobatan hipertensi di puskesmas Tanjungsari hanya menggunakan menggunakan obat Kaptopril dan Amlodipin. Sebenarnya pada pengobatan hipertensi dianjurkan jika hanya masih kategori hipertensi ringan-sedang bias dfiberikan hanya dengan obat Nifedipin dan Hidroklorotiasid (HCT) Dikarnakan obat ini efektif terhadap hipertensi ringan dan cukup aman pada penderitanya.

Kesimpulan hasil penelitian ini, yaitu didapatkan penderita hipertensi terbanyak pada usia >40 tahun, dan wanita paling banyak menderita hipertensi. Kebanyakan dari pasien tidak mengontrol tekanan darahnya secara rutin. Untuk obat yang digunakan yaitu hanya Kaptopril dan amlodipin dari golongan ACEInhibitor. Dalam hal pemberian obat di Puskesmas Tanjungsari tidak menggunakan Reserpin, Propanolol, Nifedipin dan Hidroklrotiazid. Karena obat tersebut tidak tersedia di puskesmas, obat tersebut termasuk dalam daftar obat untuk pasien ASKES. Tetapi berdasarkan Depkes 2007 standar Pengobatan Puskesmas untuk penyakit hipertensi adalah 5 yaitu Reserpin, Propanolol, Nifedipin, Hidroklrotiazid dan kaptopril.

\section{Daftar Pustaka}

Badan Penelitian dan Pengembangan Kesehatan Kementrian Kesehatan RI Tahun 2013. Riset kesehatan dasar RISKESDAS 2013 
(Internet). 2013 Cited 2015 July 13http://www.depkes.go.id/resources/downl oad/general/Hasil\%20Riskesdas\%202013

Chobanian A, The Seventh Report of the joint National Committee on Prevention, Detection, Evaluation, and Treatment of. National Institutes of Health, National Heart, Lung and Blood Institute, 2003.

Departemen Kesehatan. 2006. Pedoman Tekhnis Penemuan dan Tata Laksana Penyakit Hipertensi. Jakarta: Direktorat Pengendalian Penyakit Tidak Menular Depkes RI

Departemen Kesehatan. 2007. Pedoman Pengobatan Dasar Di Puskesmas. Jakarta

Direktorat Bina Farmasi Komunitas dan Klinik Dirjen Bina Kefarmasian dan Alat Kesehatan.2006. Pharmaceutical Care Untuk Penyakit Hipertensi. Jakarta. Depatemen Kesehatan RI.

Kasjono,Yasril.2009 Teknik Sampling untuk Penelitiana Kesehatan.Yogyakarta ;Graha Ilmu

Kemenkes RI, 2014, Pedoman pelayanan kefarmasian di puskesmas, departemen kesehatan RI, Jakarta.

Kementrian Kesehatan Republik Indonesia. 2014 Hasil Riset Kesehatan Dasar. Jakarta,

Menteri Kesehatan Republik Indonesia, Peraturan Menteri Kesehatan Republik Indonesia Nomor 75 tahun 2014 tentang pusat kesehatan masyarakat. Menteri Kesehatan Republik Indonesia, 2014

Tarigan, dkk, 2013. Pola Peresepan Dan Kerasionalan Penggunaan Antihipertensi Pada Pasien Dengan Hipertensi Di Rawat Jalan Puskesmas Simpur. Fakultas Kedokteran Unila.

Undang - Undang Kesehatan Republik Indonesia No. 36 tahun 2009 tentang Kesehatan. 111 halaman

World Health Organization. A Global brief on Hypertension : Silent Killer, Global Public Health.2015 